\title{
Por uma Teoria do "Jornalismo sem Fim"
}

\author{
Erick Felinto \\ (jornalista, doutor em letras, professor da UERJ)
}

\section{Resenha do livro}

Pena, Felipe. Teoria do Jornalismo. São Paulo: Editora Contex10, 2005.

Viver em uma época de crise e transformações constantes exige um espírito capaz de adaptação rápida e de generoso acolhimento a tudo o que é novo. No campo de estudos da comunicação, a essas exigências acrescentase ainda uma intuição especial para captar o que é essencial ao espirito do tempo. Parafraseando Pound, o pesquisador de comunicação deve. como o artista, ser uma "antena da raça". Seu mister é traduzir em reflexão e conceito o estado da cultura no momento presente. O novo livro de Felipe Pena, Teoria do Jornalismo, cumpre essas demandas com doses iguais de rigor e elegância.

No frio mundo dos manuais, o trabalho de Pena se destaca como um texto vivo e pulsante. Ele é exaustivo em sua descrição do estado da arte de seu objeto, ao mesmo tempo em que claro e prazeroso no estilo da escrita. Dedicado eminentemente aos estudantes de graduação, freqüentemente sufocados nos cursos pelo etemo dilema entre teoria e prática. Teoria do Jornalismo se inicia precisamente com uma meditação extremamente pessoal sobre o despropósito de tal embate.

Digo "pessoal", pois o livro de Pena comete, nesse sentido, duas heresias acadêmicas: opta por escrever em primeira pessoa e entremeia a apresentação de conceitos e teorias com referências a experiências de vida. Assim fazendo, demonstra que não existe teoria que não se radique na realidade e não existe prática que não se alimente da teoria.

Essas escolhas também refletem. em alguma medida, a sintonia do texto com o a atualidade. O livro dialoga com certa tendência recente do discurso acadêmico, em especial no mundo anglo-saxão, de reaproximar o observador do objeto observado. Trata-se de uma tendência que opta por denegar o hermetismo do tradicional jargão universitário em benefício de um texto cristalino e agradável, mas denso e original. como testemunham, por exemplo, algumas obras recentes de teóricos como Hans Ulrich Gumbrecht (Production of Presence, Stanford University Press. 2004) e Steven Shaviro (Connected, or what it means to live in the Netwok Socien. University of 
Minnesota Press, 2003). Ao mesmo tempo, essa pessoalidade radiçal da escrita denuncia, indiretamente, um dos grandes mitos do jornalismo - um mito partilhado por longo tempo com os discursos da ciência: a ịdéị da neutralidade do observador.

Felipe Pena recusa tal neutralidade no momento em que oferece ao leitor um breve relato do trabalho que desenvolvera como Diretor de curso e Sub-Reitor de uma grande universidade particular, antes de passar a integrar o quadro de docentes da UFF. Por meio desse relato, o leitor entende que vida e obra são inseparáveis ${ }^{1}$, configurando um campo de experiência e reflexão que foi objeto de um estudo anterior do autor, Teoria da Biografia sem Fim (Mauad, 2004). Ali, Pena evocava os célebres versos de Fernando Pessoa para definir o jornalista como um fingidor. Finge acreditar no real que descreve, quando, bem no fundo, sabe que "o máximo que pode oferecer é um efeito de real" (2004: 15). No novo livro, sugere que a origem do jornalismo encontrase no medo; medo diante do desconhecido, do devir incerto que buscamos pacificar por meio das tentativas de prevê-lo e descrevê-lo.

É pouco provável que essas afirmativas sejam acolhidas com prazer pelos jornalistas, mas a tarefa da teoria, como bem lembrava Paul de Man, é resistir (e, por outro lado, quanto mais se resiste a ela, mais ela floresce) $)^{2}$. Para a teoria do jornalismo, a grande missão consiste, segundo Pena, em entender por que as notícias são como são e quais são os efeitos gerados por essas notícias (2005: 17). Com o objetivo de abordar essas questões - e sem a pretensão de oferecer respostas finais - o texto de Teoria do Jornalismo flui com leveza através de uma sequiência lógica que abarca três grandes partes: conceitos e histórias, teorias e críticas e tendências e alternativas. Ao final de cada subdivisão, o leitor encontra breves indicações de bibliografia complementar, material valioso para o estudante ansioso diante da escassez de estudos na área. Esse cuidado com o estudante é complementado pela excelente bibliografia comentada ao final do volume.

Sabemos que os manuais costumam sofrer por sua superficialidade e caráter lacunar. Teoria do Jornalismo busca evitar esses problemas - até certo ponto incontornáveis -, contemplando o mais abrangente leque possível de teorias e idéias, das tradicionais hipóteses do gatekeeping e da espiral do silêncio às teses da nova história e à "teoria gnóstica" do jornalismo. Assim fazendo, não deixa também de incorrer em alguns riscos, por vezes talvez excessivos. Poderíamos perguntar se é mesmo legítimo, por exemplo, propor uma teoria gnóstica para o jornalismo, uma vez que não existe qualquer tradição de estudos nesse sentido, e que o pensamento gnóstico, como forma de esoterismo voltado à manutenção de segredos iniciáticos, parece inteiramente avesso à missãa jornalística da objetividade e da publicização dos fatos. Pena lembra oportunamente que a classe dos jornalistas (como, de resto, qualquer classe profissional) possui seus rituais, práticas iniciáticas 
e hierarquias, mas cabe perguntar até que ponto é lícito comparar essa estrutura com a complexidade da organização social e dos cultos de natureza gnóstica.

Outro perigo enfrentado por um livro abrangente e aberto como o de Felipe Pena é o de situar em um mesmo patamar obras e idéias de valor desigual. Nesse sentido, alguns momentos do texto possivelmente exigiriam um olhar menos generoso e mais crítico. Se de fato. como propõe o autor. a teoria do jornalismo deve "assumir sua cientificidade". investigando evidências e construindo "enunciados passíveis de revisão e refutação" (2005: 218), ela deve estar preparada para enfrentar as resistências à teoria, as práticas petrificadas, as idéias acabadas, as interpretaçōes apressadas e o empirismo ingênuo. O jornalismo é apenas uma das muitas dimensões do campo da comunicação na contemporaneidade. Uma dimensão extremamente importante, não há dúvida, mas que nem por isso pode subtrair-se à revisão permanente de seus fundamentos e ao escrutínio do conceito e da teoria.

É nesse sentido que Teoria do Jornalismo cncontra sua maior força nos momentos em que refuta idéias como a de que "os procedimentos jornalísticos constituem um saber autônomo e auto-suficiente" (ibid.). Em um trabalho de fôlego (e de paixão) como o realizado por Felipe Pena, a coragem de assumir maiores riscos é compensada pelo extremo cuidado com leitor, futuro jornalista ou pensador do jornalismo. É a esse leitor que o livro é dedicado em última instância. Felipe Pena entende que nenhuma obra ou pensamento é fruto do intelectual solitário, gênio isolado do resto do mundo em um laboratório imaginário, como o do Fausto de Goethe. Todo texto, do jornalístico ao acadêmico, é também determinado por realidades culturais e discursos socialmente partilhados. Em Teoria do Jomalismo, encontramos esse autor múltiplo, indefinido e "fractal", para usar um termo caro ao jovem pesquisador. E a escritura que produz, igualmente múltipla, híbrida e acolhedora - quiçá uma teoria do "jornalismo sem fim" - constitui significativa contribuição aos estudos de comunicação em nosso meio.

\section{Notas}

' Nesse sentido, é exemplar a proposta de um livro como Vida e Mimesis, de Luiz Costa Lima. Rio de Janeiro: Editora 34. 1995.

${ }^{2}$ Cs. De Man, Paul. A Resistência à Teoria. Lisboa: Edições 70. 1989. p.41. 


\section{2}

CONTRACAMPO 12 